International Journal of English Literature and Social Sciences
Vol-6, Issue-5; Sep-Oct, 2021
Journal Home Page Available: $\underline{\text { https://ijels.com/ }}$ Journal DOI: $10.22161 /$ ijels

Peer-Reviewed Journal

\title{
The Subaltern and Racism in Toni Morrison's Jazz: A Study
}

\author{
Dr. Sudhir P Mathpati
}

Assistant Professor and Research Guide, Department of English, Adarsh Mahavidyalaya, Omerga, Dist. Osmanabad, Maharashtra, India

Received: 05 Sep 2021; Received in revised form: 25 Sep 2021; Accepted: 10 Oct 2021; Available online: 17 Oct 2021 (C)2021 The Author(s). Published by Infogain Publication. This is an open access article under the CC BY license (https://creativecommons.org/licenses/by/4.0/).

\begin{abstract}
The present research paper studies the treatment of the subaltern and issues of racism in Toni Morrison's Jazz. It goes into various categories of the subaltern as the various forms of subalternity, the novelist depicts in her novel. This paper explores the conditions that determine the status and situations of each form and category of the subalternity and racism portrayed in the novel. The subaltern and racism in the novel is all about the Afro - Americans who suffer pangs of being African by origin and American by virtue of living. Moreover, there are categories of the subaltern within Afro - American community and those who are not blacks. The novel portrays how Afro - American women, under the white duress, suffer at different levels. It is also a product of slavery, segregation, poverty, and deprive of a franchise.
\end{abstract}

Keywords - Subaltern, Afro - American community and women, slavery, racism, segregation, poverty.

No doubt, Toni Morrison is one of the most famous and influential authors of the second half of twentieth century America who depicts the consciousness of present man entangled in the web of life. She describes, in particular, the consciousness of Afro - Americans who had to bear offends on various levels like physical, mental, psychological and more important than these, on the racial one. Furthermore, she powerfully speaks about an Afro Americans women who have been suffering indignities in the US on account. She is being doubly oppressed as a black in America and also as a woman in a patriarchic social set up. Her writings are filled with her concern over the sad plight of her ethnicity in America. It had to suffer since its forced import from atavistic Africa its spiritual homeland.

Indeed, it seems rather enhanced and comprehensive to state that right from the childhood everyone has been taught by his/her parents, relatives, teachers, near and dears that what is good and what is bad and everyone has been told to follow whatever good in his/her lives. Accordingly, everyone tries to differentiate between these two obligatory streams of our lives.
Sometimes, some people might be failed to recognise the same but most of the times they prefer the good things. But the main thread occurs when people candidly understand what is good and what is bad and still unbendingly or unconsciously accept the dark side or bad part. People simply don't simply bother about persons who may suffer due to their stance and action. The same kind of aspect is taken by Toni Morison to make realize once again the sense of differentiate the things. In fact, Afro - American studies have its own concerned with the examination of the culture. It is namely about the black Americans of African descent. At first, black consciousness and culture were studied as a single facet of the broader field of postcolonial studies but now the picture is changed and the field has become larger than earlier one. Basically, the postcolonial studies have encouraged cultural history of whiteness in the United States of America. It is based on the idea that whiteness constructs itself at the socioeconomic costs of the minorities-especially Blacks and accordingly Toni Morrison raises quite crucial issues through her literature and $J a z z$ is one of the examples of it 
in which she talks about the subaltern beings, racism and other such significant issues.

As far as Toni Morrison is concerned, she was born in 1931 in Lorain (Ohio) and she was the second among four children. She shows her interest in literature quite early and later on she studies humanities in Howard and Cornell University and spends her academic life at Texas Southern University, Howard University and Yale University. She enters in the realm of literature, particularly novel, in 1970 with the most famous piece of literature, The Bluest Eye. She delivered countless lectures of Afro - American literature and she becomes the Nobel Prize- and Pulitzer Prize-winning novelist. He confesses that she writes about the black people and there are many white characters in her literature. Once she says, "I'm writing for black people, in the same way that Tolstoy was not writing for me, a 14-year-old coloured girl from Lorain, Ohio. I don't have to apologise or consider myself limited because I don't [write about white people] - which is not absolutely true, there are lots of white people in my books. The point is not having the white critic sit on your shoulder and approve it" (Lee, 45). She is the author of some prolific titles like The Bluest Eye (1970), Sula (1973), Song of Solomon (1977), Tar Baby (1981), Beloved (1987), Paradise (1997), Love (2003), A Mercy (2008), Home (2012), God Help the Child (2015), The Source of Self Regard (2019) and Jazz (1992).

Toni Morrison's Jazz is one of the touching and appealing novels which is set in 1920s. This novel has the historical story which deals with the dramatic love triangle of door to door salesman Joe, his wife Violet and his teenage girlfriend Dorcas. This novel has different themes like violence, motherhood, racism, marginalization or subalternity and many more issues can be found in this piece of literature by Toni Morrison.

A subaltern, lexically, is a person of inferior rank and a subordinate being who suffers from discrimination. The term, nevertheless, was first used by Antonio Gramsci to mean the economically dispossessed persons in the system. In postcolonial studies, the term has widened its scope and it becomes all inclusive. What the term connotes now relates to everyone who has been marginalized, exploited, discriminated, tortured physically, mentally and psychologically, and the one who has been turned into an 'other.' Gayatri Spivak, a noted Marxist, feminist, and deconstructionist critic, raises, and that quite emphatically, the issues of this mumbling and grumbling group in her celebrated essay Can the Subaltern Speak? What she sees in the Indian context can be invariable applied to other societies. She attempts to relocate and reestablish a voice or collective locus of agency in postcoloniality. She suggests that any attempt from the outside to improve the condition of the subaltern by granting them collective speech invariably will encounter the following problems: 1. A logocentric assumption of cultural solidarity among a heterogeneous people and 2. A dependence upon western intellectuals to 'speak for' the subaltern condition rather than allowing them to speak for themselves.

Spivak and other subaltern critics argue that it is not the economically dispossessed or possessed which reduce a person to the 'other' but the collective forces economic, political, social, physical and psychological which reduce him to a nullity. This nullifying or 'othering,' as a matter of fact, can be open or hidden, i.e. direct or indirect. If this is what the subaltern critics mean, a subaltern, then, is a person who, regardless of his social, economic, or political status, is threatened by other forces superior or higher to him leading to a hierarchy of subalternity in the society.

It is with this perspective that the present study aims to investigate the novel Jazz (1992) by Toni Morrison. It seeks to bring out various categories of subalterns. Morrison creates multiple variants of subalternity in her fictional world and keeps the question and their issues alive in her novel.

The novel studies the major themes such as slavery, segregation, racism, poverty, and disenfranchisement. In addition to this, there are many other things like: a complicated anger, the carefree indulgence of the now; a marginalized population's assertion of selfhood, of cultural vitality and artistic pride; the hope for musical synthesis through conflict. She created an era of socially allowed Afro - American invisibility and stigmatization; it is also the confirmation of individual and group worth: the soul's manifestation of its love for its complement, the rejected flesh. A tribute to the soul's resilience, it is ultimately one process through which it may heal itself. The impact of racism has been deeply highlighted by Toni Morrison and the same can be pointed out with many examples given in the said novel. The statement, "Blues Man. Black and bluesman. Black therefore blue man" (Morrison, Jazz, 119). Toni Morrison rightly uses some typical words and plays a word game to point out the influence of racism. She might be trying to show that the black people used to consider themselves blue in 1926. It was so because racism was seriously messed up at that time.

The novel involves a love triangle set in the Harlem of the 1920s, when Afro-American people were searching for better life and trying to deal with the still strong memories of slavery. The character of Dorcas, the sexy young girl who becomes the middle aged Joe Trace's 
lover (she is dead in the present of the story), is complex. Though on the one hand, she is a femme fatale and home wrecker. Morrison shows the readers that she is actually unsure of her attractiveness, having been rejected by a young man of her own age. Dorcas seems to base her sense of worth on her ability to attract men, and turns to Joe to prove this to herself. Her discarding of Joe, a man who really likes women, for the younger action, a conceited woman-hater, precipitates Joe's murder of her.

Equally interesting is Violet, Joe's rejected wife, who neglects to have children and then in her fifties finds herself taking a baby from a carriage. She develops a friendship with Dorcas's Aunt Alice that is full of an unspoken closeness both women obviously come to cherish. To some extent, Alice is one of Morrison's thin brown girls, but she is rendered much more sympathetically than in earlier novels. The most fascinating character is Joe's mother, a crazed wild woman who abandoned Joe as a baby and lives in caves.

In an interesting twist on the males searching for their fathers, Joe longs to make contact with this enigmatic mother, but he never gets her to speak. She appears to exist in that preverbal 'wild zone' that Morrison characters, male and female, sometimes penetrate, usually deriving some revelation beyond the words of the patriarchy. She is, Katherine B. Payant suggests, "a haunting image of the hurt the world inflicts on women," but she is also the "frightening image of the untamed woman entirely outside the laws of the fathers" (Morrison, Jazz, 24).

This typography accents the large number of sections and subsections to create a sense of disconnection between the novel's segments. Overall speaking, the novel tells the story of Joe and Violet Trace over more than fifty years. Both are born in rural Vesper County, Virginia, and orphaned young. Joe's mother abandons him to a neighboring family. Violet's father must be absent because his political activities are so dangerous. Unable to cope alone with the financial and emotional difficulties of her young family, Violet's mother, Rose Dear, goes mad. Joe and Violet marry young. When the nearby town of Vienna is burned by vengeful whites, they leave the Virginia countryside for New York City.

New York, is presented as the city throughout the novel to designate it as an active character, it becomes a refuge for the Afro - Americans' sufferings, subjugation and exploitation from the racist whites. In an atmosphere full of the Jim Crow attitude, Rose goes mad as she is unable to cope up with the grim situation she surrenders before. She is a subaltern who loses her existence because of the forces powerful enough to humble down an African American in America. Even Joe and Violet have to leave
Vienna for their ethnic background. They become homeless in a country that boasts of being just, equal and egalitarian. That the black Americans suffer because of the corruptive influence of racism prevalent in America is noticeably evident in the novel.

The novel opens with the narrator gossiping about Violet who has disrupted the funeral of a young girl by knifing the corpse. Later on, her husband's name, Joe Trace, and the girl]s name, Dorcas is shown. The attack is only Violet's first vengeful act. Later on, she takes a silly revenge on Joe by conducting a brief, meaningless affair in their home.

The narrator suggests that Violet's actions stem from the long ago suicide of her mother, Rose Dear. Although Violet's grandmother, True Belle, arrived to rescue her daughter from destitution and loneliness, Rose Dear did not recover from her emotional paralysis. Mentioning that True Belle tells Violet and her sister's stories about a boy named Golden Gray, the narrator hints that he will be important to our later understanding of the Traces.

Finally, the narrator notes some of Violet's oddities. Expecting a child so much, she half -consciously kidnaps a baby and when caught immediately, indignantly denies it and believes herself to be telling the truth. Violet becomes increasingly inward focused and less aware of the external world.

Once she simply sits in the street to rest, and she often makes mistakes in choosing words. By the end of the first section, the narrator communicates the outlines of Violet's history, which is fleshed out in sections number Four and Six. Joe's story is largely delayed until sections Five and Seven.

The same note of resentment and anger against the white duress is visible in the novel, where we find the black community's multilayered oppressed life in America. Through the characters of Dorcus and Violet, Morrison highlights the subjugated life of the Afro American women. One can also find a variety of oppressed class a young woman made 'other' by her lover's rejection, a man psychologically suppressed by the abandonment of his parents, and a wife mentally disturbed by her husband's love affair with a young girl. The mother of Joe represents a woman who is turned into a subaltern because of reasons unexplained in the text.

Thus, in her novel, subalternity and racism seem dominating issues and Morrison comes to term with the dual consciousness confronting Afro - Americans and also a part of the solution which must be embraced by them. The novel makes clear the fact that African people in America suffer from a crisis of their African personality, 
stemming from America's nation class oppression. This also carries a political dimension where in capitalism seems to be a big enemy in all its forms and disguises. The solution, she suggests indirectly, lies in a collective, not individual, struggle against this enemy.

To conclude, it could be said that the grounds of subalternity and racism are becoming more and more intricate with its variety of threads and approaches. Toni Morrison tries her best to unveil the hidden issues of subalternity and racism which were kept unseen under the shades of races, cultures, countries, attitudes, classes, sexes, etc. She might be trying to put before the world the realistic portrait of Afro - Americans where the issue of subalternity and racism were treated in a different way and it brought many changes in Afro-American literature. The said novel, Jazz, doesn't miss out the opportunity to highlight these crucial issues.

\section{REFERENCES}

[1] Brown, Caroline. "Golden Gray and the Talking Book: Identity as a Site of Artful Construction in Toni Morrison's Jazz." African American Review. Vol. 36: 4, 2002. Print.

[2] Cannon, Elizabeth M. "Following the Traces of Female Desire in Toni Morrison's Jazz. African American Review. Vol. 31: 2, 1997. Print.

[3] Jones, Steve. Antonio Gramsci. New York: Routledge, 2007. Print.

[4] Lee, Sherry, Quan, How Dare We Write, Modern History Press, Ann Arbor, MI, 2017. Print.

[5] Morrison, Toni. Jazz. London: Vintage Books, 1997. Print.

[6] Spivak, Gayatri Chakravorty. Can the Subaltern Speak? Marxism and the Interpretation of Culture, $\mathrm{U}$ of Illinois $\mathrm{P}$, 1988. Print. 